\title{
PENGARUH MODEL PEMBELAJARAN INKUIRI TERHADAP KARAKTER RASA INGIN TAHU SISWA DALAM PEMBELAJARAN IPA DI KELAS IV SDN 15 TELAGA BIRU KABUPATEN GORONTALO
}

\author{
Gamar Abdullah, Yuliani Taib \\ Jurusan Pendidikan Guru Sekolah Dasar (PGSD), Fakultas Ilmu \\ Pendidikan, Universitas Negeri Gorontalo
}

\begin{abstract}
The problem in this study is whether there is an influence of the inquiry learning model on the character of students' curiosity in learning science in grade IV SDN 15 Telaga Biru, Gorontalo District. The aim is to determine the effect of inquiry learning models on the character of students' curiosity in science learning in grade IV SDN 15 Telaga Biru Gorontalo district. This research was conducted using the pre-experimental design method with the design of one group pretest-posttest design. The population in this study were all fourth grade students of SDN 15 Telaga Biru. Withdrawal of the sample using saturated sampling technique, which amounted to 29 people, where all members of the population made as research samples. This study uses a questionnaire as an instrument. Based on the results of the study, there is an influence of the inquiry learning model on the character of student curiosity, with the average value of the results of the character of students' curiosity in the treatment class before using the inquiry learning model which is 69,190 and after using the inquiry learning model is 82,328 . Based on the criteria of hypothesis testing obtained $\mathrm{t}$ count $=7.974$ and $\mathrm{t}$ table $=1.70$ or $\mathrm{t}$ count $>\mathrm{t}$ table, in other words tcount is outside the acceptance area of the hypothesis $\mathrm{H} 0$ (H0 is rejected) which means accepting the alternative hypothesis (H1 accepted). This means that there is an influence of the inquiry learning model on the character of students' curiosity in science learning in grade IV SDN 15 Telaga Biru.
\end{abstract}

Keywords: Inquiry Learning Model, Character of Curiosity, Learning Science

\section{A.PENDAHULUAN}

\section{Latar Belakang Masalah}

Pendidikan dimaknai sebagai

usaha membantu siswa dalam mengembangkan potensinya untuk menghadapi masa depan. Ada dua hal penting yang harus diwujudkan dalam proses penyelenggaraan dalam pendidikan, yaitu mengembangkan kemampuan siswa dan membentuk watak siswa. Tujuan dari proses pendidikan melalui pembelajaran adalah perubahan kualitas tiga aspek pendidikan yakni, kognitif, afektif, dan psikomotor. Hal ini sesuai dengan yang diungkapkan oleh 
PEDAGOGIKA

Jurnal Ilmu Pendidikan

Volume 9 (Nomor 2) 2018

Barnawi dan Arifin dalam Asriani

mengembangkan potensinya dengan et.al (2017:1456) bahwa tujuan pembelajaran ialah peningkatan wawasan, perilaku dan keterampilan dengan tujuan akhirnya adalah terwujudnya siswa yang berkarakter. Untuk mencapai tujuan tersebut, salah satu caranya adalah dengan menerapkan pendidikan karakter di sekolah, yakni dengan mengintegrasikan pendidikan karakter ke dalam setiap pelajaran yang akan diajarkan. Dengan demikian, selain untuk menjadikan siswa menguasai kompentensi, proses pembelajaran juga dirancang untuk menjadikan siswa mengenal, menyadari dan menginternalisasi nilai-nilai karakter dan menjadikannya perilaku dalam kehidupan sehari-hari.

Guru sekolah dasar memegang peranan yang sangat strategis terutama dalam mengembangkan potensi siswa sekolah dasar. Salah satu cara untuk mewujudkan manusia yang berkarakter adalah dengan mengintegrasikan pendidikan karakter dalam setiap pembelajaran. Salah satu nilai karakter yang perlu dimiliki oleh peserta didik untuk baik adalah rasa ingin tahu.

Ilmu Pengetahuan Alam (IPA), dalam proses pembelajaran seringkali siswa memiliki banyak kesulitan dalam proses pembelajaran khusunya dalam memahami materi yang akan diajarkan oleh guru. Hal ini diakibatkan kurangnya kreatif guru dalam proses pembelajaran berlangsung. Karena model pembelajaran yang digunakan hanya berfokus pada ranah kognitif saja tanpa melibatkan keterampilanketerampilan yang dimiliki oleh siswa khusunya dalam aspek afektif dan psikomotor yang dimilki siswa. Jika diterapkan hubungan yang berkesinambungan antara aspek kognitif, afektif dan psikomotor siswa tentunya guru dalam proses pembelajaran berlangsung tidak akan mengalami kesulitan dan begitu pun sebaliknya siswa tidak akan mengalami kesulitan pula dalam memahami setiap materi yang akan disajikan.

Untuk mendukung adanya karakter rasa ingin tahu dalam proses pembelajaran perlu adanya model pembelajaran yang mendukung. Dalam hal ini peneliti menggunakan 
PEDAGOGIKA

Jurnal Ilmu Pendidikan

Volume 9 (Nomor 2) 2018

model pembelajaran inkuiri dalam melihat karakter yang dimiliki oleh siswa khusunya karakter siswa (rasa ingin tahu). Menurut Gulo dalam Haryanti (2014:11) model inkuiri merupakan suatu rangkaian kegiatan pembelajaran yang melibatkan seluruh kemampuan siswa untuk mencari dan menyelediki secara sistematis dan logis sehingga mereka dapat merumuskan penemuannya dengan percaya diri.

Berdasarkan hasil observasi yang dilaksanakan pada tanggal 12 Januari 2018 di SDN 15 Telaga Biru Kabupaten Gorontalo menunjukan bahwa pada proses pembelajaran IPA masih mengalami berbagai macam kendalam dalam penggunaan model pembelajaran inkuiri. Masalahnya adalah guru terlalu sulit untuk menerapkan model pembelajaran, dimana karakter rasa ingin tahu siswa belum terlihat sepenuhnya, sedangkan keterbatasan waktu dalam proses pembelajaran hanya sedikit, jadi sangat sulit bagi siswa untuk menumbuhkan rasa ingin tahu.

Beberapa hasil penelitian sebelumnya menunjukan bahwa karakter yang dimilki siswa khusunya rasa ingin tahu tidak akan muncul sendiri secara baik bila siswa tidak menemukan lingkungan yang membentuk pendidikan karakter siswa khusunya rasa ingin tahu siswa sejak awal. Menurut Sulistiyorini dalam Susanto (2016:169) bahwa ada sembilan aspek yang perlu dikembangkan dalam pembelajaran IPA yakni, sikap ingin tahu, ingin mendapat sesuatu yang baru, sikap kerja sama, tidak putus asa, tidak berprasangka, mawas diri, bertanggung jawab, berpikir bebas, dan kesidiplinan diri. Sembilan aspek yang ada pada pembelajaran IPA berkaitan erat dengan karakter siswa khusunya rasa ingin tahu siswa. Rasa ingin tahu merupakan suatu tingkah laku untuk mengetahui dan terus mencari tahu terhadap suatu permasalahan. Rasa ingin tahu merupakan salah satu aspek dalam pendidikan karakter yang mengarah pada cara berpikir, sikap dan perilaku yang mencerminkan rasa penasaran dan keingintahuan terhadap segala hal yang dilihat, didengar dan dipelajari secara lebih mendalam.

\section{Rumusan Masalah}


PEDAGOGIKA

Jurnal Ilmu Pendidikan

Volume 9 (Nomor 2) 2018

Rumusan masalah dalam penelitian ini yaitu apakah terdapat pengaruh model pembelajaran inkuiri terhadap karakter rasa ingin tahu siswa dalam pembelajaran IPA di kelas IV SDN 15 Telaga Biru Kabupaten Gorontalo?

\section{Tujuan Penelitian}

Penelitian ini bertujuan untuk mengetahui pengaruh model pembelajaran inkuiri terhadap karakter rasa ingin tahu siswa dalam pembelajaran IPA di kelas IV SDN 15 Telaga Biru Kabupaten Gorontalo.

\section{B.KAJIAN TEORITIS DAN HIPOTESIS}

\section{Karakter Rasa Ingin Tahu}

Karakter adalah watak, tabiat, akhlak, atau kepribadian seseorang yang terbentuk dari hasil internalisasi berbagai kebajikan (virtues), yang diyakini dan digunakan sebagai landasan untuk cara pandang, berpikir, bersikap dan bertindak (Wibowo, 2013:10). Karakter identik dengan akhlak, sehingga karakter merupakan nilai-nilai perilaku

manusia yang universal yang meliputi seluruh aktivitas manusia, baik dalam rangka berhubungan dengan Tuhan, diri sendiri, sesama manusia, maupun dengan lingkungan, yang terwujud dalam pikiran, sikap, perasaan, perkataan, dan perbuatan berdasarkan normanorma agama, hukum, tata krama, budaya, dan adat istiadat.

Karakter rasa ingin tahu adalah sikap dan tindakan yang selalu berupaya untuk mengetahui lebih mendalam dan meluas dari sesuatu yang dipelajarinya, dilihat, dan didengar (Fathurrohman, 2013:20). Sedangkan Kurniawan (2016:148) nilai karakter rasa ingin tahu di lingkungan sekolah yaitu membawa kejutan-kejutan kepuasan dalam diri siswa dan meniadakan rasa bosan untuk belajar. Jika jiwa siswa dipenuhi dengan rasa ingin tahu akan sesuatu, mereka akan dengan segala keinginan dan kesukarelaan akan mempelajarinya. Setelah memuaskan rasa ingin tahunya, mereka akan merasakan betapa menyenangkan hal tersebut.

Untuk melihat tumbuhnya rasa ingin tahu, maka diperlukan beberapa indikator. Indikator 
PEDAGOGIKA

Jurnal Ilmu Pendidikan

Volume 9 (Nomor 2) 2018

tersebut menunjukkan perilaku siswa dalam pembelajaran yang mencerminkan munculnya karakter rasa ingin tahu. Rasa ingin tahu dapat dilihat dengan munculnya beberapa perilaku siswa berupa:

Menggunakan beberapa alat indera untuk menyelidiki materi,

Mengajukan pertanyaan tentang objek dan peristiwa. Memperlihatkan minat pada hasil percobaan (Achmad, 2017:30).

Menurut Oktaviani (2017:5) indikator rasa ingin tahu siswa di kelas adalah: (1) Menunjukan kemampuan berpikir kritis, logis, dan kreatif, (2) Menunjukan keterampilan menyimak, membaca dan menulis, (3) Membuka pemikiran mereka terhadap hal-hal baru ataupun hal-hal yang mereka pelajari, (4) Selalu banyak bertanya, (5) Membaca beragam jenis bacaan untuk mengeksplor dunia mereka, (6) Tidak menerima sesuatu pembelajaran sebagai sesuatu yang membosankan dan menarik, dan (7) Terlihat dan memahami ketika dalam pembelajaran terasa menyenangkan

\section{Model Pembelajaran Inkuiri}

Model pembelajaran dapat dikatakan sebagai suatu deskripsi dari lingkungan belajar yang menggambarkan perencanaan kurikulum, kursus-kursus, desain unit-unit pelajaran dan pembelajaran, perlengkapan belajar, buku-buku pelajaran, buku-buku kerja program multimedia, dan bantuan melalui program komputer (Suprihatininggrum, 2016:143).

Model pembelajaran inkuiri merupakan model pembelajaran yang dimana siswa dituntut untuk berpikir kritis, analitis dengan menemukan hal-hal yang baru dengan rasa keingintahuan mereka. Menurut Kurniasi dan Sani (2016:113) model pembelajaran inkuiri merupakan pembelajaran dengan seni merekayasa situasi-situasi yang sedemikian rupa sehingga siswa bisa berperan sebagai ilmuan. Siswa diajak untuk bisa memiliki inisiatif untuk mengamati dan menanyakan gejala alam, mengajukan penjelasanpenjelasan tentang apa yang mereka lihat, merancang dan melakukan pengajuan untuk menunjang atau menentang teori-teori mereka, menganalisis data, menarik kesimpulan dari data eksperimen, 
PEDAGOGIKA

Jurnal Ilmu Pendidikan

Volume 9 (Nomor 2) 2018

merancang dan membangun model.

permasalahan yang dikaji; (4) model inkuiri adalah rangkaian Mengumpulkan data, siswa kegiatan pembelajaran yang menjaring informasi yang menekankan pada proses berpikir secara kritis dan analitis untuk mencari dan menemukan sendiri jawaban dari suatu masalah yang dipertanyakan.

Menurut Hamalik dalam Sitiatava (2013:88) menyatakan bahwa model pembelajaran inkuiri adalah suatu strategi yang berpusat pada siswa (student centered strategy), kelompok siswa inkuiri dilibatkan dalam suatu persoalan atau mencari jawaban terhadap pertanyaan-pertanyaan di dalam suatu prosedur dan struktur kelompok yang digariskan secara jelas. Langkah-langkah model pembelajaran inkuiri menurut Sitiatava (2013:101) adalah: (1) Orientasi, guru melakukan langkah untuk membina suasana atau iklim pembelajaran yang kondusif; (2) Merumuskan masalah, merumuskan masalah merupakan langkah membawa siswa kepada suatu persoalan yang mengandung tekateki, (3) Merumuskan hipotesis, merumuskan hipotesis adalah jawaban sementara dari suatu dibutuhkan untuk menguji hipotesis yang dibuat, (5) Menguji hipotesis, siswa menguji hipotesis yang telah dirancang dengan menggunakan data yang telah didapatkan; dan (6) Merumuskan kesimpulan, siswa mendeskripsikan penemuan yang diperoleh berdasarkan hasil pengujian hipotesis.

\section{Hakikat Pembelajaran IPA}

Menurut Wisudawati dan Sulistyowati (2014:22) mendefinisikan IPA merupakan rumpun ilmu, memiliki karakteristik khusus yaitu mempelajari fenomena alam yang faktual, baik berupa kenyataan, atau kejadian dan hubungan sebab akibatnya. IPA merupakan suatu kumpulan yang sistematis penerapannya terhadap gejala-gejala alam melalui metode ilmiah seperti observasi dan eksperimen serta menuntun sikap ilmiah seperti rasa ingin tahu, terbuka, dan jujur (Melinda, 2017:68). Menurut Sugianto (2015:58) hakikat IPA dipandang sebagai proses, sebagai produk, dan 
PEDAGOGIKA

Jurnal Ilmu Pendidikan

Volume 9 (Nomor 2) 2018

sebagai prosedur. IPA harus dipandang sebagai cara berpikir dalam pencarian tentang pengertian rahasia alam, sebagai cara penyelidikan terhadap gejala alam, dan sebagai batang tubuh pengetahuan yang dihasilkan dari inkuiri.

Proses pembelajaran IPA menekankan pada pengalaman langsung agar mampu memahami alam sekitar secara ilmiah. Oleh karena itu dalam pembelajaran IPA dibutuhkan metode pembelajaran yang benar-benar ada di alam, sehingga mampu mengarahkan siswa untuk memiliki keterampilan dalam memecahkan masalah serta mampu berpikir kritis.

\section{Hipotesis Penelitian}

Berdasarkan permasalahan yang dikemukakan dalam penelitian ini, maka hipotesis yang diangkat dalam penelitian ini adalah terdapat pengaruh model pembelajaran inkuiri terhadap karakter rasa ingin tahu siswa dalam pembelajaran IPA di kelas IV SDN 15 Telaga Biru Kabupaten Gorontalo.

\section{C.METODE PENELITIAN}

Tempat dan Waktu Penelitian

Penelitian ini dilaksanakan di SDN 15 Telaga Biru, Kecamatan Telaga Biru, Kabupaten Gorontalo. Penelitian ini dilaksanakan pada semester genap tahun ajaran $2017 / 2018$.

\section{Desain Penelitian}

Penelitian ini merupakan penelitian yang menggunakan model pre experimental design dengan rancangan One Group PretestPosttest Design. Penelitian ini hanya menggunakan satu kelas, dimana peneliti akan mengukur karakter rasa ingin tahu siswa sebelum menggunakan model inkuiri dan sesudah menggunakan model inkuiri.

Variabel bebas pada penelitan ini adalah model pembelajaran inkuiri, sedangkan variabel terikatnya adalah karakter rasa ingin tahu siswa. Indikator rasa ingin tahu siswa meliputi: (1) Menunjukan kemampuan berpikir kritis, logis, dan kreatif, (2) Menunjukan keterampilan menyimak, membaca dan menulis, (3) Membuka pemikiran mereka terhadap hal-hal 
PEDAGOGIKA

Jurnal Ilmu Pendidikan

Volume 9 (Nomor 2) 2018

baru ataupun hal-hal yang mereka pelajari, (4) Selalu banyak bertanya, (5) Membaca beragam jenis bacaan untuk mengesplor dunia mereka, (6) Tidak menerima sesuatu pembelajaran sebagai sesuatu yang membosankan dan menarik dan (7) Terlihat dan memahami ketika dalam pembelajaran terasa menyenangkan.

\section{Populasi dan Sampel}

\begin{tabular}{|c|c|c|c|c|}
\hline \multirow[t]{2}{*}{ Variabel } & \multirow{2}{*}{$\begin{array}{c}\text { Indikator Karakter Rasa } \\
\text { Ingin Tahu }\end{array}$} & \multicolumn{2}{|c|}{$\begin{array}{l}\text { Nomor Butir } \\
\text { Pernyataan }\end{array}$} & \multirow[b]{2}{*}{ Jumlah } \\
\hline & & Positif & $\begin{array}{c}\text { Nega } \\
\text { tif }\end{array}$ & \\
\hline \multirow{11}{*}{$\begin{array}{l}\text { Karakter } \\
\text { Rasa } \\
\text { Ingin } \\
\text { Tahu }\end{array}$} & $\begin{array}{ll}\text { Menunjukkan } & \text { kemampuan } \\
\text { berpikir kritis } & \\
\end{array}$ & 1,3 & 4 & 3 \\
\hline & $\begin{array}{ll}\begin{array}{l}\text { Menunjukkan } \\
\text { berpikir logis }\end{array} & \text { keterampilan } \\
\end{array}$ & 2,7 & 5 & 3 \\
\hline & $\begin{array}{ll}\begin{array}{l}\text { Menunjukkan } \\
\text { berpikir kreatif }\end{array} & \text { kemampuan } \\
\end{array}$ & 8,10 & - & 2 \\
\hline & $\begin{array}{l}\text { Menunjukkan keterampilsan } \\
\text { menyimak }\end{array}$ & 11,15 & 14 & 3 \\
\hline & $\begin{array}{l}\text { Menunjukkan keterampilan } \\
\text { membaca }\end{array}$ & 16 & - & 1 \\
\hline & $\begin{array}{l}\text { Menunjukkan keterampilan } \\
\text { menulis }\end{array}$ & 19,21 & 17 & 3 \\
\hline & $\begin{array}{l}\text { Membuka pemikiran mereka } \\
\text { terhadap hal-hal baru ataupun } \\
\text { hal-hal yang mereka pelajari }\end{array}$ & 18,20 & 23 & 3 \\
\hline & Selalu banyak bertanya & 22,26 & $\begin{array}{l}25, \\
28\end{array}$ & 4 \\
\hline & $\begin{array}{l}\text { Membaca beragam jenis bacaan } \\
\text { untuk mengeksplor dunia } \\
\text { mereka }\end{array}$ & 24 & 27 & 2 \\
\hline & $\begin{array}{l}\text { Tidak menerima sesuatu } \\
\text { pembelajaran sebagai sesuatu } \\
\text { yang membosankan dan menarik }\end{array}$ & 12,30 & 6 & 3 \\
\hline & $\begin{array}{l}\text { Terlihat dan memahami ketika } \\
\text { dalam pembelajaran terasa } \\
\text { menyenanqgkan }\end{array}$ & 29,9 & 13 & 3 \\
\hline & Jumlah & & & 30 \\
\hline
\end{tabular}

Populasi pada penelitian ini adalah seluruh siswa kelas IV SDN 15 Telaga Birui tahun ajaran 2017/2018. Tehnik penentuan sampel yang digunakan ialah sampling jenuh. Jadi dalam penelitian ini sampel diambil seluruh siswa kelas IV sebanyak 29 orang.

\section{Tehnik Pengumpulan Data}

Tehnik penelitian yang digunakan meliputi angket, observasi, dan dokumentasi. Angket betujuan untuk untuk mencari data tentang karakter rasa ingin tahu siswa dalam pembelajaran IPA di kelas IV SDN 15 Telaga Biru Kabupaten Gorontalo.

Tabel 1. Kisi-Kisi Angket

Observasi ditujukan untuk mengamati proses pembelajaran dengan menggunakan model pembelajaran inquiri. Sedangkan dokumentasi dilakukan untuk mempelajari dokumen untuk memperoleh data lainnya secara langsung dari tempat penelitian, meliputi buku-buku yang relevan, peraturan-peraturan, laporan kegiatan, foto-foto, serta data yang relevan penelitian.

\section{Teknik Analisis Data}

Sebelum digunakan, angket karakter rasa ingin tahu siswa divalidasi terlebih dahulu dengan menggunakan umus produck moment 
PEDAGOGIKA

Jurnal Ilmu Pendidikan

Volume 9 (Nomor 2) 2018

menurut Riduwan (2013:97).

Posttes kepada siswa. Angket

Pengujian reliabilitas angket merupakan instrument non tes yang dilakukan dengan menggunakan rumus alpha cronbach.

Sebelum dilakukan uji hipotesis, dilakukan uji normalitas data dengan menggunakan uji Lilliefors. Setelah pengujian normalitas data dilakukan, Rata-rata skor tes angket model inkuiri menggunakan karakter rasa ingin tahu siswa diuji dengan menggunakan statistik uji $t$.

\section{D.HASIL PENELITIAN DAN}

PEMBAHASAN

\section{Deskripsi Karakter Rasa Ingin}

\section{Tahu Siswa}

Peneliti mengajar sebanyak 2

kali pertemuan dan menggunakan model yang berbeda di dalam 1 kelas (kelas perlakuan). Pada pertemuan pertama, peneliti memberikan materi terlebih dahulu sebelum memberikan pretest. Pada pertemuan ini peneliti mengajar menggunakan sarana buku pegangan guru sebagai bahan ajar. Kemudian pada pertemuan kedua peneliti menggunakan model inkuiri sebagai model pembelajaran. Kemudian setelah menyelesaikan pembelajaran, peneliti memberikan

digunakan sebagai pretest dan posttest untuk mengukur karakter rasa ingin tahu siswa kelas IV dalam mengikuti pelajaran IPA khususnya materi sumber energi setelah menggunakan model inkuiri. Angket tersebut sebelum digunakan untuk penelitian telah di uji validitas dan reliabilitas terlebih dahulu sehingga dapat digunakan untuk meneliti.

\begin{tabular}{lll}
\multicolumn{2}{c}{ Hasil penelitian } & yang \\
didapatkan & adalah berupa & data \\
deskriptif pernyataan $1-4$ & yang
\end{tabular}
memiliki skor pada masing-masing item pernyataan. Terdapat 30 item angket yang digunakan untuk meneliti karakter rasa ingin tahu siswa yang setiap pernyataan memiliki skor yang kemudian diubah menjadi data angka untuk diolah berdasarkan perhitungan kuantitatif dengan bantuan ms-excel. Berdasarkan pengolahan analisis statistik yang telah dilakukan oleh peneliti maka dapat disajikan hasil analisis data statistik deskriptif dari sebelum perlakuan dan setelah perlakuan yang frekuensinya meliputi banyaknya siswa, mean, median, modus, rentang data, data 
PEDAGOGIKA

Jurnal Ilmu Pendidikan

Volume 9 (Nomor 2) 2018

maksimum dan mimimum,

adalah 23. Dari jumlah sampel banyaknya kelas serta panjang kelas yang dapat dilihat pada tabel berikut.

Tabel 2. Deskripsi Data Hasil Angket Sebelum Perlakuan

(responden) sebesar 29 maka didapat banyaknya kelas, yaitu 6 dan panjang kelas yaitu 4. Sehingga dapat disimpulkan bahwa rata-rata karakter rasa ingin tahu siswa dalam pembelajaran IPA meningkat.

\begin{tabular}{|c|c|c|}
\hline Kriteria & $\begin{array}{c}\text { Sebelum } \\
\text { Perlakuan }\end{array}$ & $\begin{array}{c}\text { Setelah } \\
\text { Perlakuan }\end{array}$ \\
\hline $\begin{array}{c}\text { Banyaknya } \\
\text { Siswa (N) }\end{array}$ & 29 & 29 \\
\hline Mean & 69,190 & 82,328 \\
\hline Median & 69,875 & 82 \\
\hline Modus & 71,5 & 81,75 \\
\hline $\begin{array}{c}\text { Rentang } \\
\text { Data }\end{array}$ & 32 & 23 \\
\hline Maksimum & 84 & 95 \\
\hline Minimum & 52 & 72 \\
\hline $\begin{array}{c}\text { Banyaknya } \\
\text { Kelas }\end{array}$ & 6 & 6 \\
\hline $\begin{array}{c}\text { Panjang } \\
\text { Kelas }\end{array}$ & 6 & 4 \\
\hline
\end{tabular}

Dari tabel 2 dapat diketahui

bahwa skor rata-rata perolehan angket adalah 69,190 dimana skor maximumnya adalah 84 dan skor minimunnya adalah 52 sehingga didapat rentang datanya adalah 32 . Dari jumlah sampel (responden) sebesar 29 maka didapat banyaknya kelas, yaitu 6 dan panjang kelas yaitu 6.

Setelah perlakuan dapat diketahui bahwa skor rata-rata perolehan angket adalah 82,328 dimana skor maximumnya adalah 95 dan skor minimunnya adalah 72 sehingga didapat rentang datanya

\section{Pengujian Normalitas Data}

Pengujian normalitas data ini adalah syarat yang harus dipenuhi pada analisis statistik. Pengujian normalitas data ini bertujuan untuk mengetahui apakah data yang diperoleh dari hasil penelitian berdistribusi normal atau tidak. Berdasarkan hasil perhitungan yang diperoleh peneliti dari kelas perlakuan untuk data pretest Lhitung $=$ 0,075 dan $\mathrm{L}_{\text {tabel }}=0,1634$. Karena data dari pretest menunjukkan bahwa Lhitung < $\mathrm{L}_{\text {tabel }}$, maka dapat disimpulkan bahwa data pretest berasal dari populasi yang berdistribusi normal.

Kemudian hasil perhitungan untuk data posttest kelas perlakuan didapat $\mathrm{L}_{\text {hitung }}=0,137$ dan $\mathrm{L}_{\text {tabel }}=$ 0,1634. Karena data dari posttest menunjukkan bahwa $\mathrm{L}_{\text {hitung }}=0,137<$ $\mathrm{L}_{\text {tabel }}=0,1634$, maka dapat disimpulkan bahwa data posttest 
PEDAGOGIKA

Jurnal Ilmu Pendidikan

Volume 9 (Nomor 2) 2018

berasal dari populasi yang berdistribusi normal. Karena kedua sampel berasal dari populasi yang berdistribusi normal sehingga persyaratan untuk uji t dua sampel berkolerasi dependen terpenuhi. Artinya pengujian hipotesis uji t dua sampel berkolerasi dependen bisa dilakukan.

\section{Pengujian Hipotesis}

Berdasarkan hasil pengujian normalitas data didapatkan bahwa data terdistribusi normal, sehingga untuk pengujian hipotesis digunakan uji t. Pengujian ini bertujuan untuk mengetahui apakah terdapat pengaruh model pembelajaran inkuiri terhadap karakter rasa ingin tahu siswa dalam pembelajaran IPA.

Berdasarkan perhitungan dari pengujian hipotesis yang telah dilakukan peneliti, diperoleh bahwa $\mathrm{t}_{\text {hitung }}=7,974$ dan $\mathrm{t}_{\text {tabel }}=1,70$. Dengan $d k=n-1$ dan taraf signifikansi $\alpha=0,05$ atau $5 \%$. Nilai dari $t_{\text {tabel }}(1,70)$ didapat dari table uji $\mathrm{t}$ dimana $\mathrm{dk}=\mathrm{n}-1$ atau $\mathrm{dk}=29-1=28$, dimana nilai 29 yaitu jumlah dari responden sehingga didapat nilai 28. Setelah itu dapat dilihat pada table uji $\mathrm{t}$ dengan jumlah responden 29

dan taraf kepercayaan yaitu 0,95 atau 95\%, sehingga didapat nilai $t_{\text {tabel }}$ yaitu sebesar 1.70.Karena $t_{\text {hitung }}>t_{\text {tabel }}$ atau 7,974>1.70 maka $\mathrm{H}_{\mathrm{o}}$ ditolak dan $\mathrm{H}_{1}$ diterima, dimana: $\mathrm{H}_{\mathrm{o}}: \delta=0$ (tidak terdapat pengaruh model pembelajaran inkuiri terhadap karakter rasa ingin tahu siswa dalam pembelajaran IPA) dan $\mathrm{H}_{1}: \delta \neq 0$ (terdapat pengaruh model inkuiri terhadap karakter rasa ingin tahu siswa dalam pembelajaran IPA).

\section{Pembahasan}

Perubahan karakter rasa ingin tahu siswa khususnya dalam pelajaran IPA berubah dan meningkat setelah menggunakan model pembelajaran inkuiri dalam proses pembelajaran. Perubahan karakter rasa ingin tahu siswa didukung oleh aktivitas belajar siswa dalam kelas. Adapun yang menjadi pengamatan pengamat dan peneliti dalam proses pembelajaran sebelum menggunakan model pembelajaran inkuiri yaitu 1) Menjawab pertanyaan guru pada saat kegiatan apersepsi, 2) Menjawab pertanyaan guru pada saat kegiatan motivasi, 3) Menyimak pada saat guru menyampaikan tujuan pembelajaran, 
PEDAGOGIKA

Jurnal Ilmu Pendidikan

Volume 9 (Nomor 2) 2018

4) Menyimak dan mengajukan

Berdasarkan

lembar

pertanyaan apabila ada hal-hal yang belum dipahami pada saat guru menjelaskan materi pelajaran, 5)

Duduk sesuai dengan kelompoknya masing-masing, 6) Memegang materi/bahan ajar/media belajar, 7) Menerima LKS, 8) Menjawab pertanyaan yang ada dilembar LKS, 9) Mempresentasikan/menanggapi setelah menyimak materi, 10) Menanggapi dan memberi masukan kepada kelompok yang presentasi, 11) Menyimpulkan materi pelajaran, 12) Mengerjakan pretest.

Pada lembar observasi setelah menggunakan model pembelajaran inkuiri, yaitu: 1) Mengajukan pertanyaan berkaitan dengan materi, 2) Merumuskan masalah yang ditemukan, 3) Merumuskan hipotesis, 4) Melakukan eksperimen sederhana, 5) Menganalisis data, 6), Menerima LKS, 7) Menjawab pertanyaan yang ada dilembar LKS,

8) Mempresentasikan/menanggapi setelah menyimak materi, 9) Menanggapi dan memberi masukan kepada kelompok yang presentasi, 10) Menyimpulkan materi pelajaran, 11) Mengerjakan posttest. pengamatan aktivitas belajar siswa baik dari pengamat maupun peneliti selama proses belajar diketahui bahwa aktivitas belajar sebelum menggunakan model pembelajaran inkuiri atau menggunakan model pembelajaran konvensional berupa sarana buku pegangan guru, kegiatan belajar dalam kelas terkesan pasif. Artinya guru yang berperan aktif selama pembelajaran berlangsung. Hal ini dikarenakan hanya guru yang mempunyai bahan ajar sedangkan siswa hanya sebagai pendengar dan penulis dari buku yang digunakan untuk mengajar. Sedangkan saat proses pembelajaran menggunakan model pembelajaran inkuiri siswa terkesan bersemangat dan aktif dalam belajar. Hal ini disebabkan saat proses pembelajaran dengan menggunakan model pembelajaran inkuiri siswa mampu menemukan sendiri solusi dari setiap masalah yang diberikan oleh guru. Berdasarkan hasil pengujian hipotesis terbukti bahwa terdapat pengaruh model pembelajaran inkuiri terhadap karakter rasa ingin tahu siswa dalam pembelajaran IPA. 
PEDAGOGIKA

Jurnal Ilmu Pendidikan

Volume 9 (Nomor 2) 2018

Penggunaan model inkuiri memberikan pengaruh terhadap aktivitas siswa dalam belajar dan mempengaruhi karakter rasa ingin tahu siswa dalam belajar, karena model inkuiri merupakan model pembelajran yang melatih kemampuan siswa untuk mencari tahu sendiri jawaban dari suatu masalah yang diberikan oleh guru. Inkuiri sebagai suatu rangkaian kegiatan belajar yang melibatkan secara maksimal seluruh kemampuan siswa untuk mencari dan menyelidiki secara sistematis, kritis, logis, dan analitis. Sehingga mereka dapat merumuskan sendiri penemuannya dengan penuh percaya diri. Dari pendapat tersebut dapat disimpulkan bahwa pada dasarnya model inkuiri merupakan kerangka pembelajaran yang mengarahkan siswa untuk berperan aktif dalam proses pembelajaran.

Dalam penelitian ini penggunaan model inkuiri telah memberikan kesan yang berbeda dari sebelumnya, hal tersebut dapat dilihat dari tingkat karakter rasa ingin tahu siswa yang mengalami perubahan dari sebelum menggunakan dan setelah menggunakan model inkuiri telah meningkat atau dengan kata lain terdapat pengaruh model pembelajaran inkuiri terhadap karakter rasa ingin tahu siswa pada mata pelajaran IPA. Hal tersebut dikarenakan karena model pembelajaran inkuiri merupakan suatu model pembelajaran yang mengarahkan siswa untuk mencari tahu sendiri jawaban dari permasalahan yang diberikan oleh guru.

\section{E. KESIMPULAN}

\section{Simpulan}

Berdasarkan hasil penelitian yang diperoleh dapat disimpulkan bahwa terdapat pengaruh model pembelajaran inkuiri terhadap karakter rasa ingin tahu siswa dalam pembelajaran IPA di kelas IV SDN 15 Telaga Biru Kabupaten Gorontalo.

\section{REFERENSI}

Achmad, Zainudin dan Rosyid. 2017. Penguatan Karakter Rasa Ingin Tahu Dan Peduli Sosial Melalui Discovery Learning. Jurnal Teori dan Praksis

Pembelajaran IPS.2(2):280. http://journal2.um.ac.id/inde x.php/itppips/article/view/2 
500/1511. diakses: 13

Februari 2018 (07:51).

Asriani, Cholis, dan Sa'dun. 2017. Bahan Ajar Berbasis

Pendidikan Karakter Untuk Siswa Kelas IV Sekolah Dasar. Jurnal Pendidikan. Vol 2(11):1456.

http://journal.um.ac.id/index.ph p/jptpp/article/view/10160/484

7. diakses : 18 Februari 2018 (10:33).

Fathurrohman, Suryana dan Fatriany. 2013. Pengembangan

Pendidikan Karakter. Bandung: PT Refika Aditama.

Haryanti. 2014. Pengaruh Strategi Pembelajaran Inkuiri Terbimbing Terhadap Hasil Belajar Ilmu Pengetahuan Alam (Ipa) Siswa Kelas V Sd Se-Gugus Dewi Sartika Purwodadi. Yogyakarta: Universitas Negeri Yogyakarta. http://eprints.uny.ac.id/14212/1 /SKRIPSI\%20DWI\%20HARY ANTI\%2010108244013.pdf. Diakses 18 Februari 2018 (16:07).

Karwati dan Priansa.2014. Manajemen Kelas. Bandung: Alfabeta.

Kurniasih dan Sani. 2016. Ragam Pengembangan Model Pembelajaran. Jakarta: Kata Pena.

Kurniawan, S. 2016. Pendidikan Karakter.Yogyakarta: ArRuzz Media.

Lestari, K.E, Yudhanegara, M.R. (2015). Penelitian Pendidikan Matematika. Bandung: PT Refika Aditama.

Melinda. 2017. Meningkatkan Hasil Belajar Ipa Melalui Metode Inquiry Pada
Siswa Kelas V SD. Jurnal. Vol 4(1):68.

http://ejournal.upi.edu/index.ph

$\mathrm{p} /$

mimbar/article/download/6346/ pdf. diakses 18 Februari 2018 (17:50).

Oktavioni. 2017. Meningkatkan Rasa Ingin Tahu Siswa Pada Pembelajaran Ipa Melalui Model Discovery Learning Di Kelas V SD Negeri 186/1 Sridadi.

Jambi: FKIP Universitas Jambi .Artikel Ilmiah.

http://repository.unja.ac.id/133 4/1/A1D113057-

ARTIKEL.pdf. diakses 18 Februari 2018 (12:31).

Sitiatava. 2013. Desain Belajar Mengajar Kreatif Berbasis Sains. Jogjakarta: DIVA Press.

Sugianto. 2015. Pembelajaran Model Cooperative Learning Tipe Jeis Untuk Meningkatkan Sikap Ilmiah Dan Pemahaman Konsep. Journal of Primary Education. Vol.4(1):57.

https://journal.unnes.ac.id/sju/i ndex.php/jpe/article/

download/6923/4966. diakses 18 Februari 2018 (18:30).

Suprihatininggrum, J. 2016. Strategi Pembelajaran. Jogjakarta: Ar-Ruzz Media.

Susanto,A. 2016. Teori Belajar \& Pembelajaran di Sekolah Dasar. Jakarta: Prenadamedia Group.

Wahyuni. 2013. Pengaruh Penerapan Model Pembelajaran Inkuiri Dengan Mind Map Pada Pelajaran IPS Sejarah Terhadap Hasil Belajar Siswa Kelas VIII SMP $N 4$ Batang. Semarang: Universitas Negeri Semarang. 
PEDAGOGIKA

Jurnal Ilmu Pendidikan

Volume 9 (Nomor 2) 2018

Skripsi.

http://lib.unnes.ac.id/19415/1/3

101409005.pdf. diakses 18

Februari 2018 (09:36).

Wibowo, A. 2013. Manajemen

Pendidikan Karaktern Di
Sekolah. Yogyakarta:

Pustaka Pelajar.

Wisudawati dan Sulistyowati,E. 2014. Metodologi Pembelajaran IPA. Jakarta: PT Bumi Aksara. 